\title{
PHYSIOLOGICAL DISPOSITION AND METABOLIC FATE OF INFUSED PENTOSES IN MAN
}

\author{
By JAMES B. WYNGAARDEN, ${ }^{1}$ STANTON SEGAL, AND JOSEPH B. FOLEY
}

\begin{abstract}
(From the National Institute of Arthritis and Metabolic Diseases, National Institutes of Health,
\end{abstract} Bethesda, $M d$.)

(Submitted for publication December 17, 1956; accepted April 22, 1957)

In recent years there has been an increasing interest in the role of pentoses in carbohydrate metabolism. It is now clearly established that a number of pentose phosphates occur as normal intermediates in the oxidative catabolism of glucose. Although many of the reactions involving the pentoses were first encountered in studies of bacterial or plant carbohydrate metabolism, there is now evidence that mammalian tissues possess many of the same biochemical pathways.

Normal human urine regularly contains measurable quantities of the aldopentoses xylose, arabinose and ribose $(1,2)$, and of the ketopentoses, D-ribulose and L-xylulose (2-4) in addition to small quantities of glucose, fructose, fucose, galactose, sucrose, lactose, mannoheptulose and sedoheptulose $(1,2,5)$. Patients with essential pentosuria excrete gram quantities of the ketopentose, $\mathrm{L}$-xylulose, independent of diet (6-8). Ingestion of foods high in pentosan content, especially fruits and grains, is associated with a type of pentosuria called alimentary pentosuria (9). The pentose excreted reflects that ingested, generally xylose or arabinose (1). In addition, there are poorly defined pentosurias thought to be toxic or drug-induced $(10,11)$ or associated with neurological disease (1).

A further point of great interest is that certain pentoses have been shown to be insulin responsive in various experimental animals. This responsiveness, interpreted by most workers as representing a facilitation of pentose transfer across cell membranes into intracellular fluid, was first thought to be restricted to those pentoses possessing a glucose-like stereochemical constitution of carbon atoms 1 to 3 (12). Recent studies have shown, however, that insulin responsiveness is not restricted to such sugars $(13,14)$.

Because of the increasing awareness of the bio-

1 Present address : Department of Medicine, Duke University School of Medicine, Durham, N. C. logical importance of the pentoses, and because of the paucity of information regarding their metabolism in man, we have investigated certain phases of pentose metabolism in normal human subjects. This paper presents data on the physiological disposition of infused D-xylose, D-arabinose, L-arabinose, and D-lyxose in man, and observations on the effects of these pentoses on blood levels of glucose, lactate and pyruvate, and inorganic phosphorus. Data on the effects of insulin on blood levels of infused pentoses are presented in a companion paper (13). Studies have also been performed with D-ribose, but because the kinetics of its disposition, and the extent of its utilization, are quite different from the pentoses listed above, these data will be presented in a separate communication.

\section{MATERIALS AND METHODS}

D-xylose, D-arabinose, L-arabinose, and D-lyxose were obtained from Dr. Hewitt G. Fletcher, Jr., of the Section on Carbohydrates, Laboratory of Chemistry, of this Institute, or purchased from Pfanstiehl Chemical Company, Waukegan, Illinois. The purity of each sugar was checked by optical rotation (15), and when indicated the sugar was purified by recrystallization from water using alcohol and seeding to induce crystal formation (16). Ten per cent solutions, suitable for intravenous infusion, were prepared by the National Institutes of Health pharmacy and were tested and found sterile and nonpyrogenic prior to use. D-xylose-1-C ${ }^{16}$, specific activity $0.67 \mu \mathrm{c}$. per mg., was purchased from the National $\mathrm{Bu}-$ reau of Standards.

The subjects of this study were normal male and female volunteers, ranging in age from 18 to 26 years. All subjects were maintained on diets containing at least $250 \mathrm{Gm}$. of carbohydrates daily, and were fasted overnight prior to any study.

At the start of a procedure, an indwelling No. 18 polythene needle was placed in an antecubital fossa vein, and attached to a three-way stopcock, through which normal saline was infused slowly. Two blood samples were then drawn, 10 minutes apart, for control chemical determinations. These and all subsequent samples were drawn through the indwelling needle without preliminary 
stasis. After control blood and urine samples were obtained, the sugar to be studied was infused in 10- to 20$\mathrm{Gm}$. quantities in the opposite arm over a 20 -minute period. Thereafter, periodic blood samples were drawn for three hours, after which the subject was permitted to eat his normal meals. Fractional urine specimens were obtained for 24 hours, and preserved by freezing.

\section{Analytical procedures}

Glucose. Blood was collected in tubes containing fluoride and oxalate to prevent glycolysis and coagulation. Blood filtrates were prepared by the Somogyi procedure (17) and glucose was determined by the NelsonSomogyi method $(18,19)$.

Pentose. In order to determine accurately the concentrations of glucose and of pentose or other hexose when glucose and a second sugar were present simultaneously in blood or urine, we have adapted an industrial method designed to determine true glucose in mixtures of sugars (20). This method employs glucose oxidase to oxidize glucose selectively. Glucose can be measured by titration of the product, gluconic acid (20), by measurement of oxygen consumption (21), or by change in reducing power of the mixture, as in the present paper. Furthermore, once glucose is destroyed, pentose can be determined by the standard orcinol reaction without glucose interference. Glucose oxidase is relatively specific for glucose (22), acting upon its D- $\beta$-glucopyranose form (23), converting it to D-gluconolactone, and generating peroxide in the reaction. Several commercial preparations of glucose oxidase are available, all containing mutarotase (which catalyzes the interconversion of $\alpha$ and $\beta$-glucopyranose) and catalase (which destroys the peroxide). In principle, the method used in these studies was similar to that developed by Froesch and Renold (5), but since the details of the procedure developed in our laboratory were quite different, it is presented here.

\section{Procedure}

(All glassware must be scrupulously cleaned with detergent followed by sulfuric acid.)

\section{A. Blood.}

1. (a) A whole blood filtrate is prepared according to the usual Somogyi procedure (17). Two $\mathrm{ml}$. of filtrate (representing $0.2 \mathrm{ml}$. of whole blood) is placed in a 25-ml. Erlenmeyer flask to which is added $0.3 \mathrm{ml}$. of $1 \mathrm{M}$ acetate buffer, $\mathrm{pH} 5.5$, and $0.5 \mathrm{ml}$. of glucose oxidase solution, containing $2 \mathrm{mg}$. of enzyme per $\mathrm{ml}$. of distilled water.

(b) A second flask is prepared identically except that $0.5 \mathrm{ml}$. of water is added in place of the enzyme. This flask gives the total reducing value.

(c) An enzyme blank is set up containing $2 \mathrm{ml}$. of distilled water, $0.3 \mathrm{ml}$. of buffer, and 0.5 ml. of enzyme solution.
2. All flasks are incubated under $\mathrm{O}_{2}$ with agitation for three hours at $39^{\circ} \mathrm{C}$., in a Dubnoff metabolic shaker.

3. The contents of all flasks are centrifuged when particulate enzymatic material is present. Each supernatant solution is analyzed, in duplicate, for reducing material according to the procedure of Nelson and Somogyi $(18,19)$, which required $0.5 \mathrm{ml}$. of solution per determination. Duplicate aliquots of the enzyme-treated samples are used for determination of pentose with orcinol-ferric chloride according to Hurlbert, Schmitz, Brumm, and Potter (24).

4. Reference standards for calculations of true glucose content are determined for each experiment by measuring the copper reducing values of external glucose standards prepared in three different concentrations. Pentose levels are determined with reference to internal standards prepared in each experiment by adding a known amount of pentose to control blood.

B. Urine.

1. The procedure for urine is the same as for blood except that urine is diluted $1: 25$, or more if necessary, to keep glucose content less than 1.5 mg. per $\mathrm{ml}$.

2. Two $\mathrm{ml}$. of appropriately diluted urine was used instead of blood filtrate as outlined in the method for the blood assay above.

\section{Recoveries}

Known amounts of glucose or of pentose were added to whole blood in quantities simulating concentrations encountered experimentally. Recoveries of glucose averaged 94 per cent ; of D-xylose, 97 per cent ; of L-arabinose, 105 per cent; of D-arabinose, 101 per cent. Comparable recoveries were obtained from urine.

\section{Comments on the method}

1. Use of filtrates. We have found it convenient to prepare the Somogyi filtrates of blood, and freeze the filtrates until analyzed. Glucose and pentose are stable for at least eight weeks in this form. Froesch and Renold (5) have incubated hemolysates directly with large quantities of enzyme. The activity of glucose oxidase is somewhat greater in such hemolysates than in filtrates ( 8 per cent per hour, expressed as rate of glucose oxidation). However, our procedure was standardized in such a way as to permit complete destruction of glucose in blood concentrations ranging up to $1500 \mathrm{mg}$. per cent in three hours of incubation.

2. Glucose oxidase. Three different preparations were evaluated. Those purchased from Sigma Chemical Company and from Bios Biochemicals were somewhat more active by weight than that obtained from Squibb and Company. ${ }^{2}$ In equivalent quantities, in terms of ac-

2 The authors are indebted to Dr. David Perlman, Squibb and Company, New Brunswick, New Jersey, for a generous gift of glucose oxidase. 
tivity, the contributions and reducing material by these preparations were about equal by the copper reduction method. The enzyme blanks averaged about 0.048 O.D. unit at $540 \mathrm{~m} \mu$ in the Somogyi-Nelson method for all three preparations used. However, in the orcinol pentose method, the enzyme blank was 0.200 O.D. unit at $660 \mathrm{~m} \mu$ for the Bios and Sigma material but only 0.027 O.D. unit for the Squibb preparation.

3. Non-glucose reducing material in control blood. There was an average of $1.5 \mathrm{mg}$. per cent of non-glucose reducing material (expressed as glucose) in the filtrate after glucose oxidase treatment, with a range of -4 to $+5 \mathrm{mg}$. per cent. Similarly, there was an apparent average pentose concentration of $4.3 \mathrm{mg}$. per cent in fasting control blood specimens (Range, 2.6 to $6.6 \mathrm{mg}$. per cent), but since it is known that orcinol reacts with glucuronic acid (25) and certain other substances, and that the normal fasting glucuronic acid content of plasma ranges from 2.5 to $4.5 \mathrm{mg}$. per cent (26), this orcinol value cannot be regarded as representing pentose. The orcinol value obtained on control blood filtrates was subtracted from each subsequent value.

\section{Other methods}

Lactate was determined on blood filtrates according to the Mitchell and Cournand modification (27) of the method of Barker and Summerson (28). Pyruvate was determined on blood filtrates with lactic dehydrogenase according to Segal, Blair, and Wyngaarden (29). Inorganic phosphorus was determined on serum according to Fiske and Subbarow (30).

Expired $\mathrm{CO}_{2}$ was collected for timed intervals of 3 to 5 minutes in a Douglas bag through a one-way valve arrangement. Room air was inspired. $\mathrm{CO}_{2}$ and $\mathrm{O}_{2}$ content of expired air were measured in a Cambridge $\mathrm{CO}_{2}$ analyzer and a Beckman Model E2 oxygen analyzer, respectively. ${ }^{3}$ The volume of expired air was measured in a Tissot spirometer, after removal of $\mathrm{CO}_{2}$ by bubbling through $\mathrm{CO}_{2}$-free $\mathrm{N} \mathrm{NaOH}$. Carbonate was collected by precipitation with $\mathrm{BaCl}_{2}$. The $\mathrm{BaCO}_{3}$ was washed with water till the supernatant solution was no longer alkaline, and dried in vacuo at $110^{\circ} \mathrm{F}$. overnight. $\mathrm{BaCO}_{2}$ was then pulverized in a mortar, transferred to stainless steel planchets as an alcohol suspension, and counted at infinite thickness in a Robinson proportional gas-flow counter (31) having a background of 2 to 4 c.p.m., and an efficiency at infinite thinness of 53 per cent. The cumulative excretion of $\mathrm{C}^{10} \mathrm{O}_{2}$ was then determined according to Berlin, Tolbert, and Lawrence (32).

Urinary $C^{36}$ excretion was determined by counting urine in a Tricarb Liquid Scintillation counter. 4 Two-tenths $\mathrm{ml}$. of dilute urine, $2.8 \mathrm{ml}$. of alcohol, and $7.0 \mathrm{ml}$. of toluene containing 0.4 per cent 2,5-diphenyloxazole (33) were placed in a glass vial, mixed by gentle swirling, chilled, and counted to 1 per cent accuracy. Under these circum-

8 The authors gratefully acknowledge the assistance of Mrs. Harriett Coburn and Dr. Ben Branscomb of the National Heart Institute for these determinations.

- Packard Instrument Company, LaGrange, Illinois. stances the overall efficiency of counting was 45 per cent.

Urine was chromatographed on Whatman No. 1 paper in a descending system for 24 hours employing watersaturated phenol (Mallinckrodt) as solvent. After overnight air drying, the papers were sprayed with bromcresol purple-boric acid-borax solution (34) for visualization of polyhydroxy compounds, and with aniline hydrogen phthalate in n-butanol (35) for visualization of aldoses. Compounds were eluted by descending chromatography with water; eliuates were counted in the liquid scintillation counter as described above.

Periodate oxidation of urine containing $C^{14}$-xylose and possible metabolites was performed according to Eisenberg (36). Recrystallized dixanthydryl urea was prepared from urine according to Fosse (37).

\section{RESULTS}

\section{Rates of disappearance from blood of pentoses ad- ministered intravenously}

When blood levels ${ }^{5}$ of D-xylose, D- or L-arabinose, and D-lyxose, determined at various time intervals following infusion, were plotted on semilogarithmic coordinates, straight lines were obtained. A typical experiment with each sugar is illustrated in Figure 1. These results indicate that the removal of these pentoses from the blood is a first order kinetic process. The deviation of the early concentration values from the logarithmic

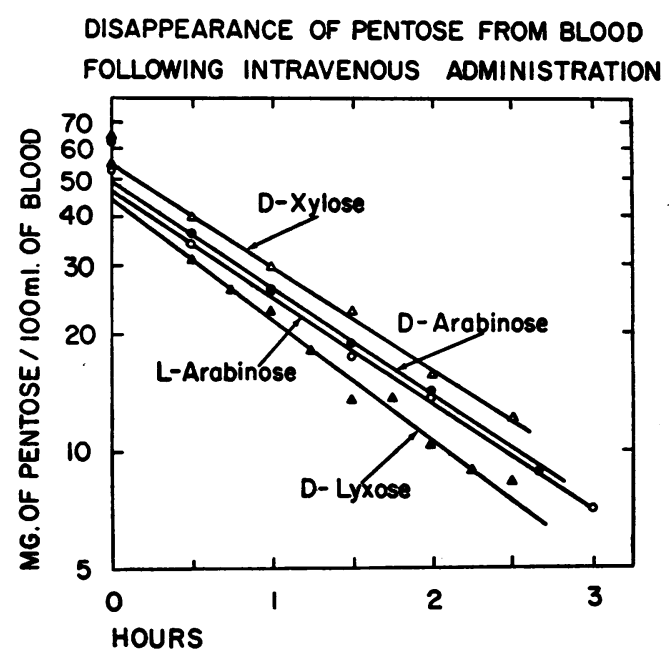

Fig. 1. Disappearance of Pentose From Blood FolLOWING INTRAVENOUS ADMINISTRATION

In the studies shown $10 \mathrm{Gm}$. of pentose was infused, and blood levels are plotted against time on hemilogarithmic coordinates.

5 The orcinol reaction is not specific for pentoses, and metabolites of the infused pentoses may be included in these values. 
TABLE I

Infusion of pentoses into normal subjects

\begin{tabular}{|c|c|c|c|c|c|c|c|}
\hline $\begin{array}{l}\text { Pentose } \\
\text { infused }\end{array}$ & $\begin{array}{l}\text { Quantity } \\
\text { infused }\end{array}$ & Subject & Weight & $\begin{array}{l}\text { Disappear- } \\
\text { ance from } \\
\text { blood }\end{array}$ & $\begin{array}{l}\text { Volume } \\
\text { of distri- } \\
\text { bution }\end{array}$ & $\begin{array}{l}\text { Urinary } \\
\text { recovery }\end{array}$ & $\begin{array}{l}\text { Blood } \\
\text { glucose } \\
\text { change }\end{array}$ \\
\hline $\begin{array}{l}\text { D-xylose } \\
\text { D-xylose } \\
\text { D-xylose } \\
\text { D-xylose } \\
\text { D-xylose } \\
\text { D-xylose } \\
\text { D-xylose } \\
\text { D-xylose } \\
\text { D-xylose } \\
\text { D-xylose } \\
\text { D-xylose } \\
\text { D-xylose } \\
\text { D-xylose }\end{array}$ & $\begin{array}{r}\text { Gm. } \\
5 \\
10 \\
10 \\
10 \\
20 \\
10 \\
10 \\
10 \\
20 \\
20 \\
10 \\
10 \\
10\end{array}$ & $\begin{array}{l}\text { W. M. } \\
\text { W. M. } \\
\text { W. M. } \\
\text { W. M. } \\
\text { W. M. } \\
\text { W. M. } \\
\text { W. R. } \\
\text { W. R. } \\
\text { W. R. } \\
\text { W. R. } \\
\text { J. B. } \\
\text { A. R. } \\
\text { A. R. }\end{array}$ & $\begin{array}{l}K_{\mathbf{g}} . \\
\mathbf{5 9 . 0} \\
\mathbf{5 9 . 0} \\
\mathbf{5 9 . 0} \\
\mathbf{5 9 . 0} \\
\mathbf{5 9 . 0} \\
\mathbf{5 9 . 0} \\
\mathbf{7 0 . 0} \\
\mathbf{7 0 . 0} \\
\mathbf{7 0 . 0} \\
\mathbf{7 0 . 0} \\
\mathbf{6 9 . 0} \\
\mathbf{7 1 . 0} \\
\mathbf{7 1 . 0}\end{array}$ & $\begin{array}{c}K^{\prime} \% / \text { min. } \\
1.58 \\
0.89 \\
1.28 \\
1.33 \\
0.89 \\
0.99 \\
1.26 \\
1.07 \\
0.90 \\
0.79 \\
0.99 \\
0.72 \\
0.72\end{array}$ & $\begin{array}{l}\text { liters } \\
16.6 \\
18.7 \\
\\
\\
13.2 \\
16.7 \\
20.4 \\
19.3 \\
18.6 \\
14.5 \\
18.5 \\
18.4\end{array}$ & $\begin{array}{c}\text { \% of admin. } \\
\text { dose } \\
44 \\
49 \\
46 \\
34 \\
38 \\
49 \\
18 \\
37 \\
42 \\
55 \\
27 \\
44 \\
41\end{array}$ & $\begin{array}{r}\text { mg. } \% \\
+25 \\
+15 \\
+10 \\
+20 \\
0 \\
+3 \\
+32 \\
+25 \\
+30 \\
+21 \\
+20 \\
+12\end{array}$ \\
\hline $\begin{array}{l}\text { D-arabinose } \\
\text { D-arabinose } \\
\text { D-arabinose }\end{array}$ & $\begin{array}{l}10 \\
10 \\
10\end{array}$ & $\begin{array}{l}\text { W. R. } \\
\text { S. B. } \\
\text { C. C. }\end{array}$ & $\begin{array}{l}70.0 \\
70.0 \\
60.0\end{array}$ & $\begin{array}{l}1.06 \\
0.92 \\
0.85\end{array}$ & $\begin{array}{l}15.1 \\
19.8 \\
11.0\end{array}$ & $\begin{array}{l}36 \\
60 \\
56\end{array}$ & $\begin{array}{l}+3 \\
-10 \\
+7\end{array}$ \\
\hline $\begin{array}{l}\text { L-arabinose } \\
\text { L-arabinose } \\
\text { L-arabinose } \\
\text { L-arabinose }\end{array}$ & $\begin{array}{l}10 \\
10 \\
10 \\
20\end{array}$ & $\begin{array}{l}\text { W. R. } \\
\text { W. M. } \\
\text { S. B. } \\
\text { C. C. }\end{array}$ & $\begin{array}{l}70.0 \\
59.0 \\
70.0 \\
60.0\end{array}$ & $\begin{array}{l}1.05 \\
0.77 \\
1.20 \\
0.94\end{array}$ & $\begin{array}{l}15.1 \\
13.9 \\
17.6 \\
20.0\end{array}$ & $\begin{array}{l}38 \\
38 \\
60 \\
52\end{array}$ & $\begin{array}{l}+11 \\
+16 \\
+18 \\
+15\end{array}$ \\
\hline $\begin{array}{l}\text { D-lyxose } \\
\text { D-lyxose }\end{array}$ & $\begin{array}{l}10 \\
20\end{array}$ & $\begin{array}{l}\text { S. S. } \\
\text { W. R. }\end{array}$ & $\begin{array}{l}84.2 \\
70.0\end{array}$ & $\begin{array}{l}1.19 \\
1.10\end{array}$ & $\begin{array}{l}16.6 \\
15.3\end{array}$ & $\begin{array}{l}37 \\
55\end{array}$ & $\begin{array}{l}-10 \\
-14\end{array}$ \\
\hline
\end{tabular}

curve probably represents a temporary distribution gradient between blood and tissues. From a knowledge of the biological half-time, a rate constant for the disappearance of pentose from blood may readily be calculated, and may be conveniently expressed in terms of per cent of pentose disappearing per minute, $\mathrm{K}^{\prime}$ equals $\mathrm{K} \times 100$.

In Table I are given the proportional rate constants of disappearance of these four pentoses. The rates of removal range from 0.72 to 1.58 per cent per minute.

Two studies were conducted in which $\mathrm{D}$-xylose was infused into patients with severe cirrhosis of the liver, accompanied by mild ascites but without icterus. These studies, described in Table II, show that the disappearance of xylose from blood

TABLE II

Rates of disappearance of infused xylose from blood in two patients with cirrhosis

\begin{tabular}{|c|c|c|c|c|c|}
\hline Subject & Sex & $\begin{array}{l}\text { Endogenous } \\
\text { creatinine } \\
\text { clearance }\end{array}$ & $\begin{array}{l}\text { Quantity } \\
\text { infused }\end{array}$ & $\begin{array}{c}\text { Disap- } \\
\text { pearance }\end{array}$ & $\begin{array}{l}\text { Urinary } \\
\text { recovery }\end{array}$ \\
\hline $\begin{array}{l}\text { McC. } \\
\text { D. R. }\end{array}$ & $\begin{array}{l}\mathbf{M} \\
\mathbf{F}\end{array}$ & $\begin{array}{c}\text { ml. } / \text { min. } \\
92 \\
81\end{array}$ & $\begin{array}{l}\text { Gm. } \\
10 \\
10\end{array}$ & $\begin{array}{c}\% / \min . \\
0.43 \\
0.49\end{array}$ & $\begin{array}{c}\% \text { admin. } \\
\text { dose } \\
47 \\
45\end{array}$ \\
\hline
\end{tabular}

was considerably slower than normal in the two cirrhotic patients. Since the glomerular filtration rates (endogenous creatinine clearances) in these subjects were not greatly reduced, these results would suggest that the liver plays an important role in the removal of xylose from the blood.

Effect of pentose on blood levels of glucose, lactate, pyruvate, and inorganic phosphate

The fasting blood glucose values ranged from 43 to $96 \mathrm{mg}$. per $100 \mathrm{ml}$. in the normal subjects (Mean, $66 \mathrm{mg}$. per $100 \mathrm{ml}$ ). Following the infusion of 5 to $20 \mathrm{Gm}$. of xylose, the blood glucose values rose in at least 10 of 13 studies performed on four individuals. These rises ranged from 10 to $32 \mathrm{mg}$. per cent, but were not well correlated with the quantity of xylose infused. The maximum glucose values were consistently recorded 30 to 40 minutes after the end of the pentose infusions, and were followed by gradual declines of blood glucose values to or below the control concentrations. Examples of these rises of blood glucose may be seen in the companion paper by Segal, Wyngaarden, and Foley (13). Similar slight rises of blood glucose were encountered after in- 
BLOOD LEVELS OF PYRUVIC AND LACTIC ACIDS, FOLLOWING XYLOSE INFUSIONS

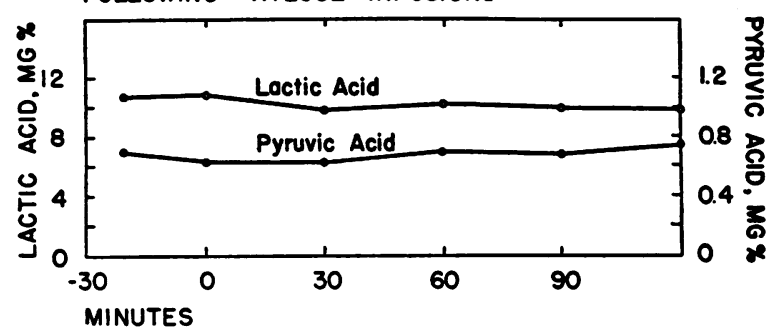

Fig. 2. Blood Levels of Pyruvic and Lactic Acids Following INFUSIONS OF D-XyLose

The results plotted are averages of values obtained in six studies. The zero point on the time ordinate represents the end of the infusion.

fusions of L-arabinose (Table I). No significant increases of blood glucose were observed following infusions of D-arabinose or D-lyxose.

Blood lactate ${ }^{6}$ and pyruvate concentrations ${ }^{7}$ were not significantly or consistently altered by infusions of pentoses (Figure 2). Although only the results following xylose infusions are shown, they are also typical of those observed following infusions of the other pentoses. These results are in striking contrast to those obtained following infusions of glucose or of fructose, which regularly cause significant rises of both of these substances $(38,40)$.

The levels of inorganic phosphate in serum consistently declined during infusions of pentose. During the infusions of D-xylose, a mean fall of $0.42 \mathrm{mg}$. per cent (expressed as phosphorus) occurred. Following the infusion, the level of phosphate gradually rose and returned essentially to control levels in two hours. In patients receiving D- or L-arabinose, or D-lyxose, an initial fall of serum inorganic phosphate was alsa observed, but this fall was of lesser magnitude. The mean re-

\footnotetext{
- Lactate and pyruvate values were determined following xylose infusion (including $2-$ to $20-\mathrm{Gm}$. infusion studies) in six instances, and following D-arabinose, L-arabinose and $D$-lyxose infusion in two instances each.

7 The apparent constancy of the lactate/pyruvate ratio in blood has impressed earlier workers $(38,39)$. In the present study this ratio has ranged from 9.5 to 18.0 in over 120 determinations on 10 individuals, including control, cirrhotic and diabetic subjects. The mean value was 14.8 , a value higher than that obtained by previous workers. This discrepancy reflects the lower values obtained for pyruvate with the specific enzymatic method than with the older procedures.
}

sponses of serum inorganic phosphorus to infusions of $10 \mathrm{Gm}$. of D-xylose (five studies), and L-arabinose (three studies), 10 or $20 \mathrm{Gm}$. of D-arabinose (three studies), and $20 \mathrm{Gm}$. of D-lyxose (one study) are shown in Figure 3.

\section{Distribution of xylose in body fluids}

In two constant infusion experiments, the rates of urinary excretion of xylose were measured and compared with the rates of intravenous infusion. In the first experiment, ${ }^{8}$ xylose was lost in the urine at a rate of $17.4 \mathrm{mg}$. per minute while being infused at a rate of $35.1 \mathrm{mg}$. per minute, over several periods when blood levels of xylose were nearly constant. In the second experiment, comparable values were 35.1 and $66.5 \mathrm{mg}$. per minute. Thus at equilibrium, 51 and 47 per cent, respectively, of the infused xylose were disappearing from the xylose compartment by non-renal mechanisms.

From knowledge of the composite rate of loss of xylose from its compartment at equilibrium (which rate is then equal to the rate of infusion), of the concentration of xylose in blood at equilibrium, and of the rate constant of xylose disappearance from blood (as determined following the completion of the xylose infusion), a volume of distri-

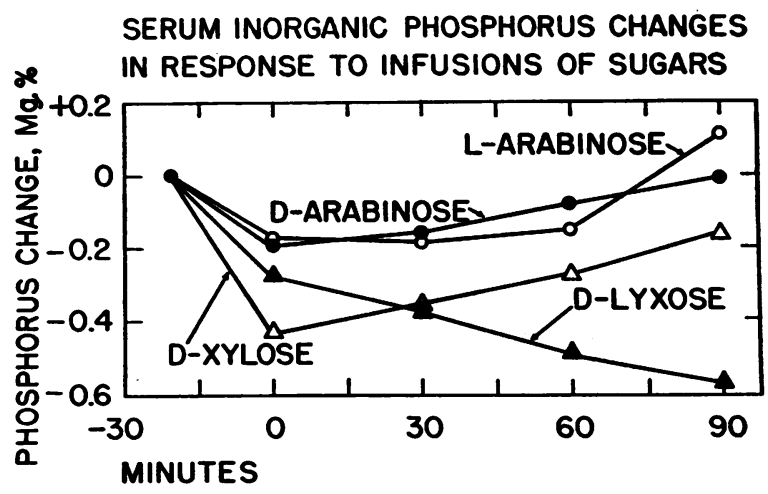

Fig. 3. Average Serum Inorganic Phosphorus Changes in Response to Intravenous Infusion of Pentoses

$\mathrm{D}$-xylose and $\mathrm{L}$-arabinose were given in $10-\mathrm{Gm}$. quantities; D-arabinose and D-lyxose in $20-\mathrm{Gm}$. quantities.

8 In this study $5 \mathrm{Gm}$. of xylose was infused as a priming dose over a 20 -minute period, followed by an additional $5 \mathrm{Gm}$. of xylose at a rate of $35.1 \mathrm{mg}$. per minute. In the second constant infusion study the quantity of primer and the rate of infusion were doubled. 
bution $^{2}$ of the xylose present in the body during equilibrium may be calculated.

Let $\mathrm{V}=$ Volume of distribution at equilibrium, in $\mathrm{L}$.

$\mathrm{C}^{\prime}=$ Concentration of xylose in plasma water at equilibrium, in $\mathrm{mg}$. per $\mathrm{L} .=$ $\mathrm{C} / 0.80$.

$\mathrm{K}=$ Rate of disappearance of xylose from its compartment, in fraction per minute.

$\mathrm{R}=$ Rate of xylose infusion at equilibrium, in $\mathrm{mg}$. per minute.

Then,

$$
\begin{gathered}
V C^{\prime}=R \\
V=R / C^{\prime} K
\end{gathered}
$$

By this method, ${ }^{10}$ volumes of distribution of xylose of 11.5 and 13.4 liters were calculated at equilibrium for the two constant infusion experiments. These volumes were smaller than those calculated from $\mathrm{C}_{0}^{\prime}$ values obtained by graphic extrapolation of the xylose disappearance curved to $t_{0}$, which averaged 17.3 liters ${ }^{11}$ in 10 studies on four subjects (Table I). This discrepancy may be attributed to the inherent difficulty of knowing $\mathrm{C}_{0}$ accurately by this method when the test substance has fates other than simple distribution and excretion $(46,47)$. The subject of this study weighed $59 \mathrm{Kg}$; t therefore, the xylose compartment $(12.5 \mathrm{~L} . / 59 \mathrm{Kg} . \times 100)$ was equal to 21.2 per cent of body weight, a figure greater than extracellular fluid, though somewhat lower than the value obtained for the volume of xylose distribution in dogs ( 26 to 30 per cent of body weight) by Dominguez, Goldblatt, and Pomerene (43).

\footnotetext{
9 Xylose has been shown to be present in erythrocyte water in approximately the same concentration as in plasma water (41). However, the entrance of xylose into the erythrocyte appears to be dependent upon an active transport mechanism, rather than upon simple diffusion (42). The volumes of distribution presented have been calculated on an assumption of equal distribution throughout intra- and extra-cellular water of blood. The concentration of xylose in plasma water $\left(C^{\prime}\right)$ has been calculated from the analytical value on whole blood (C) divided by 0.8 , the approximate water content of blood.

10 For a theoretical development of these intuited relationships see Dominguez, Goldblatt, and Pomerene (43), and Jokipii and Turpeinen (44).

$11 \mathrm{~V}=\mathrm{Q} / \mathrm{C}_{0}^{\prime}$, in which $\mathrm{C}_{0}^{\prime}=\mathrm{C}_{0} / 0.8$, the concentration of pentose in plasma water (see text) at the theoretical moment of mixing, and $Q$ is the quantity infused (45).
}

The volumes of distribution of D- and L-arabinose, and of $\mathrm{D}$-lyxose have also been calculated from the $\mathrm{C}_{0}^{\prime}$ data (Table I). The range of these values is quite comparable to those encountered in the studies with $\mathrm{D}$-xylose with this method of calculation, both as to space in liters and as to the percentage of body weight occupied by the pentose compartment. They are probably in error by about the same percentage ( 38 per cent too high) as in the case of D-xylose, but they do indicate that all of the pentoses studied are largely distributed in extracellular fluid. In this connection it is of interest to note that D-xylose has been shown to penetrate hepatic and renal tissue but not appreciably into muscle in the rat (48) under ordinary circumstances.

\section{Urinary excretion of pentoses}

The urinary excretion of pentoses was followed for 24 hours in almost all subjects. In control subjects known to excrete only trivial amounts of glucose normally, pentose was measured directly by the orcinol method without employment of glucose oxidase. In a few studies pentose excretion was checked by the more specific but far less sensitive $p$-bromaniline method (49), and excellent agreement with the orcinol results was found.

The urinary recoveries of infused pentoses are also shown in Table I. Approximately one-third to one-half of the quantity infused was recovered in urine as orcinol reactive material, and again there is no striking departure from this range for any specific pentose, although considerable variation is noted. The mean urinary excretion for all the pentoses was 43.5 per cent of the administered dose (Range, 27 to 60 per cent, neglecting one value of 18 per cent, which is probably in error). It is of interest that in the cirrhotic subjects (Table II) the urinary recoveries of infused xylose are well within the normal range.

\section{Disposition of label following intravenous injection of $x y l o s e-1-C^{14}$}

In an effort to obtain information on the fate of the relatively large fraction of xylose which does not appear as orcinol reactive products in urine following its intravenous infusion, two experiments were performed in which the disposition of the isotope was determined following intravenous ad- 


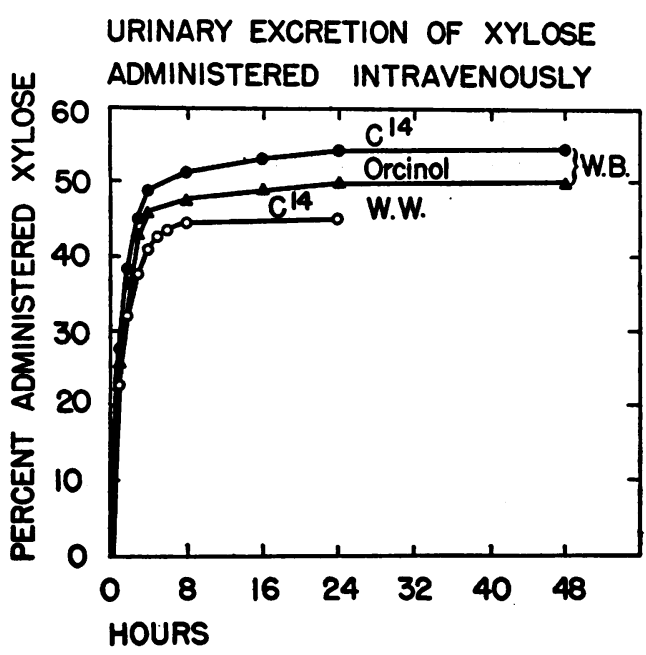

Fig. 4. Cumulative Urinary Excretion of Pentose and of $\mathrm{C}^{16}$ Following Intravenous Administration of D-XYLOSE-1-C ${ }^{24}$

Subject W.B. received $20 \mathrm{Gm}$. of D-xylose containing $4.85 \mu \mathrm{c}$. of $\mathrm{C}^{14}$. Subject W.W. received $5.7 \mathrm{mg}$. of D-xylose containing $3.8 \mu \mathrm{c}$. of $\mathrm{C}^{44}$.

ministration of xylose-1-C ${ }^{14}$. In one study $4.85 \mu \mathrm{c}$. of xylose-1-C $\mathrm{C}^{14}$ and $20 \mathrm{Gm}$. of unlabeled xylose were infused from the same flask, and the appearance of label as expired $\mathrm{C}^{14} \mathrm{O}_{2}$ was determined, as well as the excretion of label in hourly urine specimens. The concomitant administration of carrier xylose permitted comparison of urinary excretions of $\mathrm{C}^{14}$ and of orcinol reactive products in each specimen. In a second study, $3.8 \mu \mathrm{c}$. of xylose-1- $\mathrm{C}^{14}$ was infused as a tracer dose (5.7 mg.) into a second individual and only urinary excretion of label was determined. The results are shown in Figures 4, 5, and 6. Figure 4 shows that the cumulative urinary excretion of administered xylose was 54 per cent, measured as $\mathrm{C}^{\mathbf{1 4}}$, and 50 per cent, measured by orcinol reaction. The $\mathrm{C}^{14}$ value may include traces of xylose metabolites, including traces of labeled bicarbonate and urea. In the second study, 45 per cent of the label appeared in urine, so that both load and tracer doses of xylose appear to be handled similarly in the body. In Figure 5 are plotted the rates of urinary excretion of xylose, measured by $\mathrm{C}^{14}$ and orcinol methods. These results again indicate that the disappearance of xylose from blood is in part due to a first order excretion process. The half-time of xylose excretion in urine is of the same order as that of its disappearance from blood.

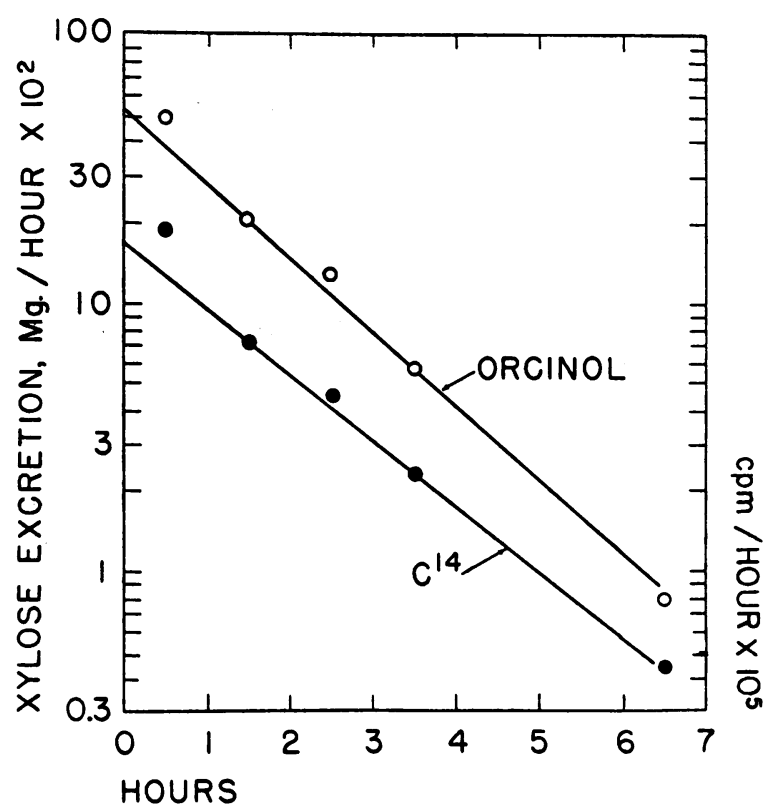

Fig. 5. Rates of Urinary Excretion of Pentose AND OF $C^{16}$ Following Intravenous Administration of D-XYLOSE-1-C

This subject (W.B.) received $20 \mathrm{Gm}$. of D-xylose containing $4.85 \mu$ c. of $\mathrm{D}$-xylose-1-C ${ }^{16}\left(5.7 \times 10^{\circ}\right.$ c.p.m. $)$.

When urine was chromatographed, virtually all of the $\mathrm{C}^{14}$ recovered was found in the xylose band, suggesting that the orcinol reactive substance represented unaltered xylose, and less than 0.1 per cent traveled in the bands opposite markers of xylitol or D-xylonolactone, two possible early metabolites. In agreement with these results, less than 0.1 per cent of the label appeared in $\mathrm{CO}_{2}$ obtained from periodate treatment of urine from which gaseous $\mathrm{CO}_{2}$ had been removed. This result excludes xylonic acid as a significant urinary product.

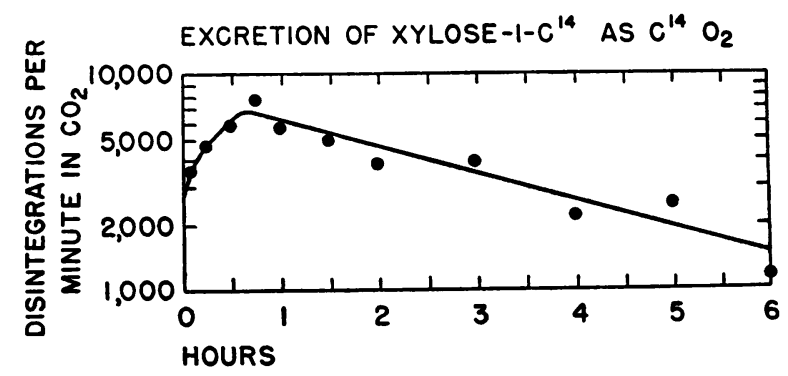

Fig. 6. EXcretion OF D-XyLOSE-1-C $\mathrm{C}^{14} \mathrm{O}_{2}$

The total $\mathrm{C}^{\mathrm{H}}$ excreted in $\mathrm{CO}_{2}$, expressed as disintegrations per minute in a one-minute sample of $\mathrm{CO}_{2}$, has been plotted against time in hours. 
The expired carbon dioxide was found to be maximally labeled 45 minutes following the end of the xylose- $\mathrm{C}^{14}$ infusion, although the first $\mathrm{CO}_{2}$ sample, collected five minutes after the end of the 10-minute infusion was already appreciably labeled (Figure 6). The cumulative $\mathrm{C}^{14} \mathrm{O}_{2}$ expiration represented 13.5 per cent of the administered label, and $\mathrm{C}^{14}$ was present in expired $\mathrm{CO}_{2}$ in detectable amounts for six hours.

The finding that labeling of respiratory $\mathrm{CO}_{2}$ was maximal 45 minutes following the infusion of xylose is quite comparable to results obtained in dogs (50) and man (51) following infusion of labeled glucose, and indicates that there is a lag of about three-fourths of an hour between removal of xylose or glucose from blood and delivery of $\mathrm{CO}_{2}$ derived therefrom to the lung. In the case of glucose, these results are well explained by a correlation of the glucose disappearance time and the half-time of the bicarbonate pool turnover which is 30 to 45 minutes in dogs (50, Discussion, p. 52) and man (52). The similarity of the $\mathrm{CO}_{2}$ labeling pattern following infusion of labeled xylose probably indicates that the intermediary pools between xylose and $\mathrm{CO}_{2}$ have rapid turnovers, as in the case of glucose (50, Discussion, $\mathrm{p}$.

TABLE III

Comparison of rates of disappearances from pentoses and hexoses from blood

\begin{tabular}{lccc}
\hline \hline Sugar & $\begin{array}{c}\text { Rate of } \\
\text { disappearance } \\
\text { from blood }\end{array}$ & $\begin{array}{c}\text { Urinary } \\
\text { excretion }\end{array}$ & Reference \\
\hline D-galactose & $\% /$ min. & $\begin{array}{c}\text { \% of admin. } \\
\text { dose }\end{array}$ & \\
D-fructose & 6.93 & 10 & $(52)$ \\
D-glucose & 3.84 & 4 & $(38)$ \\
D-mannose & $3.47^{*}$ & 2 & $(38,53)$ \\
D-lyxose & 1.82 & 45 & $(54)$ \\
D-xylose & 1.14 & 46 & This paper \\
L-arabinose & 0.98 & 42 & This paper \\
D-arabinose & 0.96 & 47 & This paper \\
& 0.94 & 51 & This paper
\end{tabular}

* The kinetics of disappearance of infused glucose are complicated by the natural presence of considerable glucose in blood. The $\mathrm{K}$ value listed is based on analysis of intravenous glucose tolerance tests by a plot of the logarithm of the blood glucose concentration in excess of the fasting value, against time. Analysis on the basis of total blood glucose concentration yields an average $K$ value for glucose of about $1.5(55,56)$. However, this value is not constant, but increases as the glucose load increases, whereas the $K$ value calculated from the glucose increment data is constant at various glucose loads (56). We are in agreement with Duncan (56) that calculations employing glucose increments are based on a more reasonable physiological premise.
52). Indeed, as discussed later, some of these intermediates may be identical.

Urinary urea, isolated as its dixanthydryl derivative, was found to contain $\mathrm{C}^{14}$ in small amounts, the concentration being clearly maximal in the second-hour specimen. This labeling of urea reflected the utilization of $\mathrm{C}^{14} \mathrm{O}_{2}$ in the formation of urea via ornithine and arginine, but quantitatively represented no more than 0.2 per cent of the $\mathrm{C}^{14}$ found even in the second-hour specimen. The close temporal correspondence between the peaks of expired $\mathrm{CO}_{2}$ and urinary urea labeling is of interest, and indicates that the metabolic and excretory time lags in the processes of formation and excretion of urea are short.

The fate of the residual 32 per cent of the administered label is obscure, as is that of the lower four carbons of the xylose whose first carbon appeared as $\mathrm{CO}_{2}$. Attempts to follow $\mathrm{C}^{14}$ excretion in later urine specimens showed that no more than 0.2 per cent of the administered isotope appeared on days 2 or 3 .

\section{DISCUSSION}

The rates of disappearance from blood of the pentoses D-xylose, D-arabinose, L-arabinose, and D-lyxose are considerably slower than those of the hexoses D-glucose, D-fructose, D-galactose, or D-mannose. Table III lists the half-times of disappearance of these sugars from blood following intravenous injection, in order of decreasing rate. It is of interest that there is a rather close correlation between the order of these rates and of the order of rates of absorption from the intestinal lumen. In order of decreasing rate of absorption, the data show D-galactose, D-glucose, D-fructose, D-xylose, D-mannose, L-xylose, L-arabinose (5759). This apparent similarity need not, of course, imply common mechanisms.

In the present study the mean excretion of intravenously administered D-xylose was 42 per cent, of $\mathrm{D}$-arabinose, 51 per cent, of L-arabinose, 47 per cent, and of D-lyxose, 46 per cent. These figures in man are in good agreement with the few published values of $\mathrm{D}$-xylose and L-arabinose recoveries in man $(41,60)$, and with limited animal data obtained with $D$-xylose in dogs (43) and rabbits $(61,62)$, and with $\mathrm{L}$-arabinose in rabbits (63). It is of interest also that intravenously administered L-xylulose is well utilized by the dog, 
only 6 and 14 per cent appearing in the urine as compared with 60 and 65 per cent of infused D-xylose (64).

Xylose excretion has been carefully studied at a renal level. Almost no urinary excretion occurs in the aglomerular fish whereas rapid renal excretion is found in glomerular fish (65). In several species xylose/inulin clearance ratios ranged from 0.60 to 0.82 (66), but when plasma glucose concentration was raised to $300 \mathrm{mg}$. per $100 \mathrm{ml}$., a level high enough to saturate the glucose reabsorbing mechanism, the xylose/creatinine clearance ratio in the dog increased to 1.0 (67). The reabsorptive process, therefore, appears to be an active one involving the glucose transport system.

In the dog, xylose excretion has been found to be linearly related to plasma concentration (43). From our data also it would appear that the logarithmic disappearance curve of xylose from plasma is in part attributable to a first order excretion process. No work has been published relating to the renal handling of the arabinoses or of lyxose to the authors' knowledge.

The fate of the pentoses escaping rapid excretion required consideration. Early work in animals failed to show clearly that the pentoses were converted to glycogen. Although such a fate was claimed for D-xylose in the rat by Thomas, Gradinescu, and Imas (68), this was not confirmed by Miller and Lewis (69). And, although Rice and Roe (70) found D-arabinose administration to increase liver glycogen in fasted rabbits, Bloom and Stetten (71) found that D-arabinose-1- $C^{14}$ and $\mathrm{D}$-arabinose-5- $\mathrm{C}^{14}$ did not give rise to significant yields of $\mathrm{C}^{14} \mathrm{O}_{2}$ either when incubated with rat liver slices or when administered to intact rats and rabbits.. In our studies there do appear to be slight increases of blood glucose following infusions of D-xylose and L-arabinose. Similarly, Brien, Turner, Watson, and Geddes (72) report rises of blood glucose following $25-\mathrm{Gm}$. oral doses of D-xylose. Metabolism of xylose has now been demonstrated clearly. Since $\mathrm{C}^{14}$ appeared in $\mathrm{CO}_{2}$ within 15 minutes of the start of the infusion of labeled xylose, it is not likely that bacterial degradation of xylose in the gastrointestinal canal can be held responsible. Furthermore, the kinetic characteristics of appearance of $\mathrm{C}^{14}$ in $\mathrm{CO}_{2}$ are comparable to those found after glucose- $\mathrm{C}^{14}$ infu- sion (51, 50, Discussion, p. 52), and this finding further suggests that xylose is in part rapidly metabolized.

The utilization of pentoses raises questions regarding the manner of their entry into mammalian metabolic pathways. The drop in serum level of inorganic phosphate occurring during pentose infusions and noted also following oral administration of D-xylose (72), suggests the possibility of initial or early phosphorylation. The only mammalian pentose kinase thus far identified and purified is D-ribokinase (73). In bacterial systems the aldopentoses are generally first isomerized to their ketopentose derivatives $(74,75)$ before phosphorylation occurs $(75,76)$.

Present knowledge of pentose metabolism is summarized in Figure 7. Those pathways known to occur in mammalian tissue are marked with an "M." Pathways marked with a "?" have not yet been demonstrated to occur in biological systems but are suspected to exist. Unmarked pathways are those known to exist in plant or bacterial systems but not demonstrated in mammalian systems. ${ }^{12}$ Free pentoses employed in this study are underscored for emphasis.

A reasonable hypothesis for the entry of $\mathrm{D}$-xylose into general pathways of mammalian carbohydrate metabolism can be offered. D-xylose is converted to $\mathrm{D}$-xylulose by xylose isomerase $(75,76)$. D-xylulose is then phosphorylated at the expense of ATP to form D-xylulose-5-phosphate (77). The number 1 carbon atom of xylulose phosphate (corresponding to the position of $\mathrm{C}^{14}$ in the xylose-C $\mathrm{C}^{14}$ employed) eventually becomes C-1 of fructose-6-phosphate and would be lost as $\mathrm{CO}_{2}$ in either the phosphogluconic acid oxidation cycle or in the Krebs cycle. During the period of logarithmic disappearance of xylose from blood, 27 per cent of the retained xylose was accounted for as $\mathrm{C}^{14} \mathrm{O}_{2}$. In the case of glucose- $\mathrm{C}^{14}$, about 60 per cent of the glucose disappearing per unit time is delivered as $\mathrm{C}^{14}$ to $\mathrm{CO}_{2}(51)$. In this case the residual 40 per cent is presumed to have entered non-carbohydrate pools and to have been utilized in part for tissue synthesis. In the case of xylose, similar fates may be presumed at least in part, since by known pathways a portion of the

12 The authors are indebted to Dr. Bernard L. Horecker for helpful discussions in constructing and labeling this schematic diagram. 


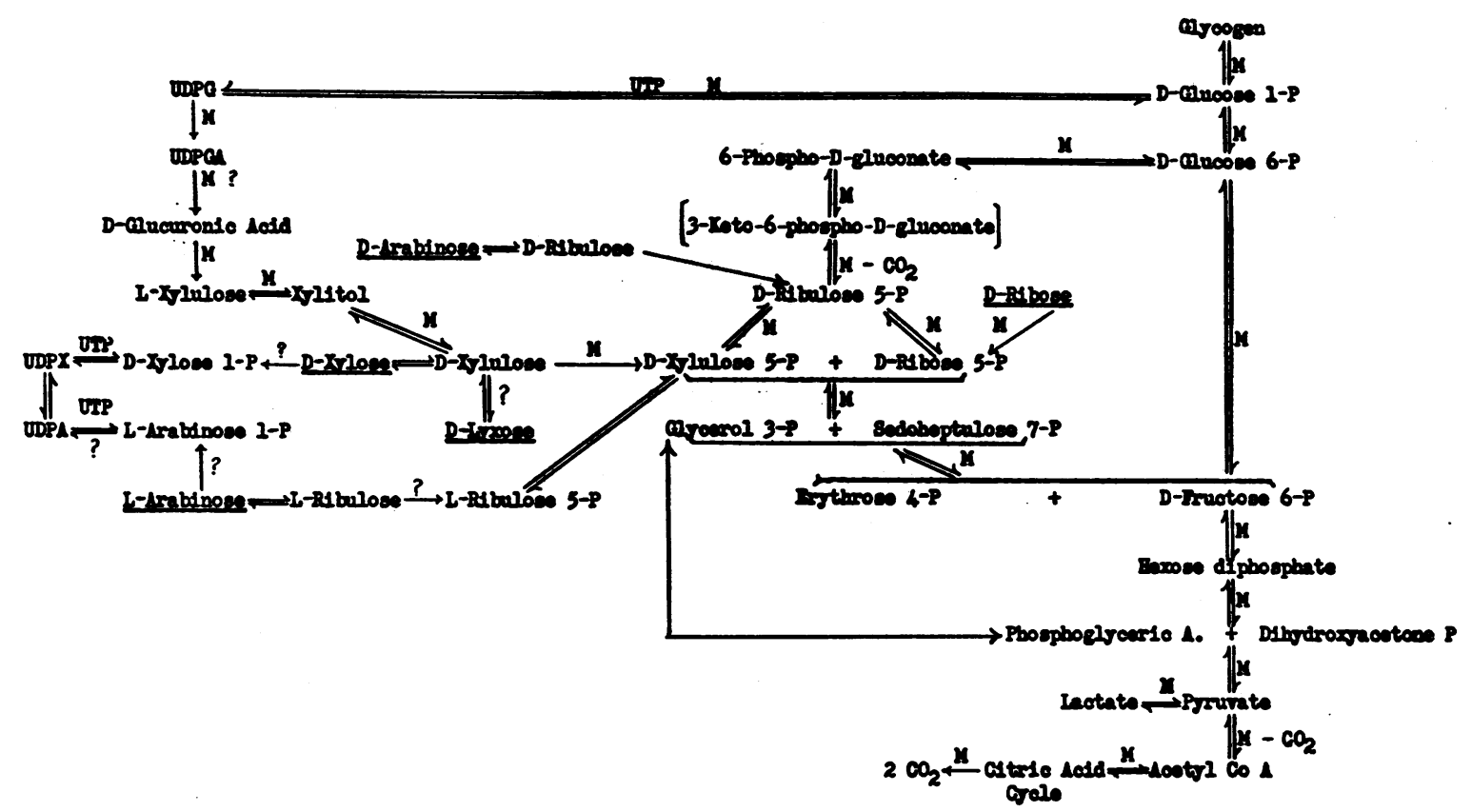

Fig. 7. Schematic Diagram of Pathways of Pentose Metabolism

Pathways marked with an " $M$ " have been demonstrated to occur in mammalian systems. Pathways marked with a "?" have not been demonstrated to occur in any biological system, yet are thought probable on the basis of related reactions. Pathways not marked with either symbol are known bacterial or plant reactions, but have not as yet been demonstrated in mammalian tissues. UTP $=$ uridine triphosphate. UDPG $=$ uridine diphosphate glucose. UDPGA, UDPX and UDPA = uridine diphosphate glucuronic acid, uridine diphosphate xylose and uridine diphosphate arabinose, respectively. The brackets around 3-keto-6-phospho-D-gluconate indicate that this intermediate has not yet been isolated.

metabolized xylose would yield glucose-6-phosphate as a product. The observations that serum inorganic phosphate falls during xylose infusion, that blood glucose tends to rise slightly 30 to 45 minutes later, and that no change of blood pyruvate or lactate occurs are all in keeping with the proposed interpretations of xylose utilization. The lack of lactate or pyruvate rises may be a reflection of the slowness of conversion of xylose to gluose, and is reminiscent of a similar lack of change of lactate or pyruvate following intravenous D-mannose infusions (54), even though the phosphorylation of mannose (78) and subsequent conversion to glucose or fructose esters are well known mammalian reactions (79).

In the case of the arabinoses also, the reactions upon which a tentative interpretation may be predicated (Figure 7) have not all been demonstrated to occur in mammalian tissue, yet they appear likely mechanisms to explain the metabolism of the non-excreted fractions of the infused sugars, and all are known biological reactions. The possibility of pentose transformations as components of nucleotides (80) must also be borne in mind.

Almost no information exists regarding pathways of metabolism of D-lyxose. A possible point of entry into the known metabolic channels is via D-xylulose. Isomerization of the pentoses $\mathrm{D}$-xylose $\rightleftharpoons \mathrm{D}$-xylulose $\rightleftharpoons \mathrm{D}$-lyxose, suggested by this scheme, would be analogous to that occurring with $\mathrm{D}$-glucose $\rightleftharpoons \mathrm{D}$-fructose $\rightleftharpoons \mathrm{D}$-mannose, the respective hexose analogues of the three pentoses. The hexose tautomerizations actually involve the phosphate esters rather than the free sugars (79), and tautomerization of the pentoses as phosphate esters is another possibility. By either of these proposed routes $\mathrm{D}$-lyxose might be anticipated to have approximately the same metabolic fates as D-xylose.

In addition to these pentose pathways, there is scattered evidence for the existence of various mammalian pentose dehydrogenases. D-glucose dehydrogenase of liver acts on D-glucose, galactose, arabinose, and xylose $(81,82)$; a partially 
purified dehydrogenase of lamb's liver acts on D-glucose, D-arabinose, D-lyxose, and possibly $\mathrm{D}$-xylose, as well as on certain phosphorylated hexoses (83); a dehydrogenase from cat liver acts on D-glucose, D-arabinose, glyceraldehyde, glycolaldehyde, and possible D-erythrose (84). The products of the dehydrogenation of pentoses are unknown, but would probably involve pentonic acids, by analogy with the dehydrogenase reactions involving glucose (81). However, if xylonic acid is a product of such reactions in man, it must be further metabolized, for no evidence for its occurrence in urine was obtained in this study.

\section{SUMMARY}

Following their infusion intravenously into normal subjects, the aldopentoses $\mathrm{D}$-xylose, $\mathrm{D}$-arabinose, L-arabinose, and D-lyxose disappear from blood at rates proportional to concentration. The half-times of disappearance were similar for the four pentoses, and averaged 71 minutes. Approximately 40 per cent of the administered pentoses were recovered unchanged in the urine. The pentoses were shown to be distributed initially in a volume of body water somewhat larger than that of extracellular water. The rate of disappearance of xylose from blood was considerably slower than normal in two cirrhotic subjects.

The infusion of each of the pentoses was accompanied by a significant drop in the serum level of inorganic phosphate, but no change in the blood levels of lactate or pyruvate were observed. Slight rises of blood glucose levels were frequently observed following infusions of $\mathrm{D}$-xylose or L-arabinose.

Limited studies with D-xylose-1-C $\mathrm{C}^{\mathbf{1 4}}$ have shown that this sugar is in part rapidly metabolized, giving rise to labeling of expired $\mathrm{CO}_{2}$. No significant labeling of urinary products other than of the unchanged D-xylose was detected.

The metabolism of the non-excreted portions of these pentoses was discussed in terms of present concepts of carbohydrate metabolism in mammalian systems.

\section{REFERENCES}

1. Tower, D. B., Peters, E. L., and Pogorelskin, M. A., Nature and significance of pentosuria in neuromuscular diseases. Neurology, 1956, 6, 37, 125.

2. White, A. A., and Hess, W. C., Paper chromatographic detection of sugars in normal and dystro- phic human urines. Arch. Biochem. \& Biophys., 1956, 64, 57.

3. Futterman, S., and Roe, J. H., The identification of ribulose and L-xylulose in human and rat urine. J. Biol. Chem., 1955, 215, 257.

4. Touster, O., Hutcheson, R. M., and Reynolds, V. H., The formation of L-xylulose in mammals and its utilization by liver preparations. J. Am. Chem. Soc., 1954, 76, 5005.

5. Froesch, E. R., and Renold, A. E., Specific enzymatic determination of glucose in blood and urine using glucose oxidase. Diabetes, 1956, 5, 1.

6. Levene, P. A., and Laforge, F. B., Note on a case of pentosuria. J. Biol. Chem.; 1914, 18, 319.

7. Greenwald, I., The nature of the sugar in four cases of pentosuria. J. Biol. Chem., 1930, 88, 1, and 1930, 89, 501.

8. Enklewitz, M., and Lasker, M., The origin of L-xyloketose (urine pentose). J. Biol. Chem., 1935, 110, 443.

9. Johnstone, R. W., Pentosuria, chronic and alimentary. Edinburgh M. J., 1906, 20, 138.

10. Margolis, J. I., Chronic pentosuria and migraine. Am. J. M. Sc., 1929, $177,348$.

11. Coover, M. O., Feinberg, L. J., and Roe, J. H., Effect of gold, adrenocorticotropic and thyroid hormone on urinary excretion of pentose in the rat. Proc. Soc. Exper. Biol. \& Med., 1950, 74, 146.

12. Levine, R., and Goldstein, M. S., On the mechanism of action of insulin in Recent Progress in Hormone Research. New York, Academic Press, 1955, 11, 343.

13. Segal, S., Wyngaarden, J. B., and Foley, J., The effect of insulin on blood levels of infused pentoses in man. J. Clin. Invest., 1957, 36, 1383.

14. Helmreich, R., and Cori, C. F., Some problems of permeability of tissue cells to sugars in Ciba Foundation Colloquia on Endocrinology. London, J. \& A. Churchill Ltd., 1956, 9, 227.

15. Browne, C. A., and Zerban, F. W., Physical and Chemical Methods of Sugar Analysis. New York, John Wiley and Sons, Inc., 1941.

16. Fletcher, H. G., Jr., Diehl, H. W., and Hudson, C. S., Improvements in the preparation of $D$-arabinose from calcium D-gluconate and of D-lyxose from calcium D-galactonate. J. Am. Chem. Soc., 1950, 72, 4546.

17. Somogyi, M., Determination of blood sugar. J. Biol. Chem., 1945, 160, 69.

18. Nelson, N., A photometric adaptation of the Somogyi method for the determination of glucose. J. Biol. Chem., 1944, 153, 375.

19. Somogyi, M., A new reagent for the determination of sugars. J. Biol. Chem., 1945, 160, 61.

20. Whistler, R. L., Hough, L., and Hylin, J. W., Determination of D-glucose in corn sirups by use of glucose dehydrogenase. Anal. Chem., 1953, 25, 1215.

21. Keilin, D., and Hartree, E. F., The use of glucose oxidase (notatin) for the determination of glucose 
in biological material and for the study of glucoseproducing systems by manometric methods. Biochem. J., 1948, 42, 230.

22. Keilin, D., and Hartree, E. F., Properties of glucose oxidase (notatin). Biochem. J., 1948, 42, 221.

23. Keilin, D., and Hartree, E. F., Specificity of glucose oxidase (notatin). Biochem. J., 1952, 50, 331.

24. Hurlbert, R. B., Schmitz, H., Brumm, A. F., and Potter, V. R., Nucleotide metabolism. II. Chromatographic separation of acid-soluble nucleotides. J. Biol. Chem., 1954, 209, 23.

25. Lefevre, K. U., and Tollens, B., Untersuchungen uber die Glucuronsaure, ihre Quantitative Bestimmung und ihre Farbenreaktionen. Ber. deut. chem. Ges., $1907,40,4513$.

26. Dowben, R. M., The fate of sodium glucuronate and glucuronolactone in man. J. Clin. Invest., 1956, 35, 277.

27. Mitchell, A. M., and Cournand, A., The fate of circulating lactic acid in the human lung. J. Clin. Invest., 1955, 34, 471.

28. Barker, S. B., and Summerson, W. H., The colorimetric determination of lactic acid in biological material. J. Biol. Chem., 1941, 138, 535.

29. Segal, S., Blair, A. E., and Wyngaarden, J. B., An enzymatic spectrophotometric method for the determination of pyruvic acid in blood. J. Lab. \& Clin. Med., 1956, 48, 137.

30. Fiske, C. H., and Subbarow, Y., The colorimetric determination of phosphorus. J. Biol. Chem., 1925, 66, 375.

31. Robinson, C. V., Windowless, flow type, proportional counter for counting $C^{44}$. Science, 1950, 112, 198.

32. Berlin, N. I., Tolbert, B. M., and Lawrence, J. H., Studies in glycine-2-C $\mathrm{C}^{16}$ metabolism in man. $\mathrm{I}$. The pulmonary excretion of $\mathrm{C}^{14} \mathrm{O}_{2}$. J. Clin. Invest., 1951, 30, 73.

33. Hayes, F. N., Rogers, B. S., and Sanders, P. C., Importance of solvent in liquid scintillators. Nucleonics, 1955, 13, 46.

34. Bradfield, A. E., and Flood, A. E., Soluble carbohydrates of fruit plants. Nature, 1950, 166, 264.

35. Partridge, S. M., Aniline hydrogen phthalate as a spraying reagent for chromatography of sugars. Nature, 1949, 164, 443.

36. Eisenberg, F., Jr., Degradation of isotopically-labeled glucose via periodate oxidation of gluconate. J. Am. Chem. Soc., 1954, 76, 5152.

37. Fosse, R., Analyze quantitative gravimetrique de l'uree dans l'urine. Compt. rend. Acad. d. sc., 1914, $158,1588$.

38. Smith, L. H., Jr., Ettinger, R. H., and Seligson, D., A comparison of the metabolism of fructose and glucose in hepatic disease and diabetes mellitus. J. Clin. Invest., 1953, 32, 273.

39. Stotz, E., and Bessey, O. A., The blood lactate-pyruvate relation and its use in experimental thiamine deficiency in pigeons. J. Biol. Chem., 1942, 143, 625.
40. Miller, M., Drucker, W. R., Owens, J. E., Craig, J. W., and Woodward, H., Jr., Metabolism of intravenous fructose and glucose in normal and diabetic subjects. J. Clin. Invest., 1952, 31, 115.

41. Keith, N. M., Power, M. H., and Peterson, R. D., Renal excretion of xylose after intravenous injection in man. Proc. Staff Meet., Mayo Clinic, 1934, 9, 43.

42. Wilbrandt, W., Die Wirkung des Phlorizins auf die Permabilitat der Menschlichen Erythrocyten fur Glukose and Pentosen. Helvet. physiol. et pharmacol. acta, 1947, 5, C64.

43. Dominguez, R., Goldblatt, H., and Pomerene, E., Kinetics of the excretion and utilization of xylose. Am. J. Physiol., 1937, 119, 429.

44. Jokipii, S. G., and Turpeinen, O., Kinetics of elimination of glucose from the blood during and after a continuous intravenous injection. J. Clin. Invest., 1954, 33, 452.

45. Widmark, E. M. P., Studies in the concentration of indifferent narcotics in blood and tissues. Acta med. Scandinav., 1920, 52, 87.

46. Dominguez, R., and Pomerene, E., Kinetics of the disappearance of galactose from the plasma after a rapid intravenous injection. Am. J. Physiol., 1944, 141, 368.

47. Peterson, R. E., Wyngaarden, J. B., Guerra, S. L., Brodie, B. B., and Bunin, J. J., The physiological disposition and metabolic fate of hydrocortisone in man. J. Clin. Invest., 1955, 34, 1779.

48. Miller, M. M., and Lewis, H. B., Pentose metabolism. II. The pentose content of the tissues of the white rat after the oral administration of $d$-xylose. J. Biol. Chem., 1932, 98, 141.

49. Roe, J. H., and Rice, E. W., A photometric method for the determination of free pentoses in animal tissues. J. Biol. Chem., 1948, 173, 507.

50. Strisower, E. H., and Searle, G. L., Turnover and oxidation of glucose in normal and diabetic animals in Major Metabolic Fuels. Upton, Long Island, Brookhaven National Laboratory, 1952.

51. Baker, N., Shreeve, W. W., Shipley, R. A., Incefy, G. E., and Miller, M., $C^{14}$ studies in carbohydrate metabolism. I. The oxidation of glucose in normal human subjects. J. Biol. Chem., 1954, 211, 575.

52. Stenstam, T., Peroral and intravenous galactose tests. Acta med. Scandinav. 1946, Suppl. 177.

53. Amatuzio, D. S., Stutzman, F. L., Vanderbilt, M. J., and Nesbitt, S., Interpretation of the rapid intravenous glucose tolerance test in normal individuals and in mild diabetes mellitus. J. Clin. Invest., 1953, 32, 428.

54. Wyngaarden, J. B., Segal, S., and Foley, J., Unpublished results.

55. Conard, V., Franckson, J. R. M., Bastenie, P. A., Kestens, J., and Kovacs, L., Etude critique du triangle d'hyperglycémie intraveineux chez l'homme normal et détermination d'un "coefficient d'assimi- 
lation glucidique." Arch. internat. pharmacodyn. et de therap., 1953, 93, 277.

56. Duncan, L. J. P., The intravenous glucose tolerance test. Quart. J. Exper. Physiol., 1956, 41, 85.

57. Cori, C. F., The fate of sugar in the animal body. I. The rate of absorption of hexoses and pentoses from the intestinal tract. J. Biol. Chem., 1925, 66, 691.

58. Larson, H. W., Blatherwick, N. R., Bradshaw, P. J., Ewing, M. E., and Sawyer, S. D., The metabolism of $l$-xylose. J. Biol. Chem., 1940, 136, 1.

59. Hele, M. P., Phosphorylation and absorption of sugars in the rat. Nature, 1950, 166, 786.

60. McCance, R. A., and Madders, K., The comparative rates of absorption of sugars from the human intestine. Biochem. J., 1930, 24, 795.

61. Corley, R. C., Pentose metabolism. I. The disposal of intravenously administered xylose in the rabbit. J. Biol. Chem., 1926, 70, 521.

62. Fishberg, E. H., The rate of disappearance of foreign sugar from the blood stream. J. Biol. Chem., 1930, 86, 665 .

63. Corley, R. C., Pentose metabolism. II. Factor affecting the disposal of L-arabinose and D-xylose in the rabbit. J. Biol. Chem., 1928, 76, 23.

64. Greenwald, I., The possible significance of $l$-xyloketose (urine pentose) in normal metabolism. J. Biol. Chem., 1931, 91, 731.

65. Jolliffe, N., The excretion of xylose by glomerular and aglomerular kidneys. Proc. Soc. Exper. Biol. \& Med., 1930, 28, 5.

66. Smith, H. W., The Kidney. Structure and Function in Health and Disease. New York, Oxford University Press, 1951.

67. Shannon, J. A., The tubular reabsorption of xylose in the normal dog. Am. J. Physiol., 1938, 122, 775.

68. Thomas, P., Gradinescu, A., and Imas, R., L'utilisation des pentoses dans l'organisme animal. Compt. rend. Acad. d. sc., 1929, 188, 664.

69. Miller, M. M., and Lewis, H. B., Pentose metabolism. II. The pentose content of the tissues of the white rat after oral administration of d-xylose. J. Biol. Chem., 1932, 98, 141.

70. Rice, E. W., and Roe, J. H., A study of the metabolism of D-arabinose in the rabbit. J. Biol. Chem., 1951, 188, 463.
71. Bloom, B., and Stetten, DeW., Jr., Personal communication.

72. Brien, F. S., Turner, D. A., Watson, E. M., and Geddes, J. H., A study of carbohydrate and fat absorption from the normal and diseased intestine in man. Gastroenterolgy, 1952, 20, 287.

73. Agranoff, B. W., and Brady, R. O., Purification and properties of calf liver ribokinase. J. Biol. Chem., 1956, 219, 221.

74. Cohen, S. S., Studies on D-ribulose and its enzymatic conversion to D-arabinose. J. Biol. Chem., 1953, 201, 71.

75. Mitsuhashi, S., and Lampen, J. O., Conversion of D-xylose to D-xylulose in extracts of Lactobacillus pentosus. J. Biol. Chem., 1953, 204, 1011.

76. Stumpf, P. K., and Horecker, B. L., The role of xylulose 5-phosphate in xylose metabolism in Lactobacillus pentosus. J. Biol. Chem., 1956, 218, 753.

77. Hochster, R. M., Conversion of D-xylose to D-xylulose phosphate by extracts of Pseudomonas hydrophila. Biochim. et. biophys. acta., 1955, 16, 292.

78. Crane, R. K., and Sols, A., Animal tissue hexokinases, in Methods of Enzymology, S. P. Colowick, and N. O. Kaplan, Eds. Academic Press Inc., New York, 1955, 1, 277.

79. Slein, M. W., Phosphohexose isomerases. Federation Proc. 1954, 13, 299.

80. Ginsburg, V., Stumpf, P. K., and Hassid, W. Z., The isolation of uridine disphosphate derivatives of D-glucose, D-galactose, D-xylose, and L-arabinose from mung bean seedlings. J. Biol. Chem., 1956, 223, 977.

81. Strecker, H. J., and Korkes, S., Glucose dehydrogenase. J. Biol. Chem., 1952, 196, 769.

82. Korkes, S., In discussion of Levine, R., and Goldstein, M. S., Effect of insulin on rate of transfer of sugars across cell barriers in Major Metabolic Fuels. Upton, Long Island, Brookhaven National Laboratories, 1952.

83. Wainio, W. W., The oxidation of phosphorylated and non-phosphorylated sugars by mammalian liver. J. Biol. Chem., 1947, 168, 569.

84. Breusch, F. L., Uber Einige Neue Zuckerdehydrogenasen in der Leber. Enzymologia, 1943, 11, 87. 